\title{
Mass stranding of Argonauta nodosa Lightfoot, 1786 (Cephalopoda, Argonautidae) along the Uruguayan coast (southwestern Atlantic)
}

\author{
Varamiento masivo de Argonauta nodosa Lightfoot, 1786 (Cephalopoda, Argonautidae) \\ a lo largo de la costa uruguaya (Atlántico suroeste)
}

\section{Mario Demicheli ${ }^{1}$, Ana Martínez ${ }^{2}$, Leonardo Ortega ${ }^{2}$, Fabrizio Scarabino ${ }^{1,2}$, Susana Maytía ${ }^{1}$ and Alvaro Demicheli ${ }^{1}$}

\author{
${ }^{1}$ Museo Nacional de Historia Natural y Antropología, C. C. 399, C. P. 11.00, Montevideo, Uruguay \\ ${ }^{2}$ Dirección Nacional de Recursos Acuáticos, Constituyente 1497, C. P. 11200, Montevideo, Uruguay \\ anamart@dinara.gub.uy
}

\begin{abstract}
Resumen.- Un varamiento masivo de $A$. nodosa fue registrado a lo largo de $250 \mathrm{~km}$ de la costa uruguaya entre enero y abril del 2004. Este evento inusual estuvo asociado con condiciones oceanográficas y meteorológicas singulares que advectaron aguas oceánicas cálidas hacia la costa, penetrando incluso en el estuario del Río de la Plata. Este es el primer registro de un varamiento masivo de cefalópodos argonáutidos en el Atlántico sudoeste.

Palabras clave: Mollusca, Octopoda, oceanografía, Río de la Plata, Uruguay
\end{abstract}

\begin{abstract}
A mass stranding of A. nodosa was registered along more than $250 \mathrm{~km}$ of the Uruguayan coast between January and April 2004. Such unusual event was associated with singular oceanographic and meteorological conditions that advected oceanic warm waters toward the shore, reaching inside the Río de la Plata estuary. This is the first record of a mass stranding of argonautid cephalopods in the southwestern Atlantic Ocean.
\end{abstract}

Key words: Mollusca, Octopoda, oceanography, Río de la Plata, Uruguay
Three species of the octopod genus Argonauta Linnaeus 1758 have been mentioned for Uruguay: Argonauta argo Linnaeus, 1758, Argonauta hians Lightfoot, 1786 and Argonauta nodosa Lightfoot, 1786 (Scarabino 2003). However, most of the individuals collected until now in Uruguayan waters were referred as A. nodosa (Barattini \& Ureta 1961, Figueiras \& Sicardi 1974, Juanicó \& Rodríguez-Moyano 1976, Leta 1983, Nion et al. 1983, Haimovici \& Andriguetto 1986). In fact, this species is the only one whose presence in these waters is repeatedly recorded; the records of $A$. argo and $A$. hians seems to be incorrect (Demicheli \& Scarabino unpublished information).

Uruguayan shelf waters were considered part of the distribution area of $A$. nodosa, without discussion on its permanence there along the year (Leta 1983). Haimovici \& Andriguetto (1986) recorded this species from Rio Grande do Sul (Brazil) and Uruguay only in summer, in agreement with the strongest influence of oceanic warm waters on those coasts. Only isolated individuals are casted ashore in the Uruguayan Atlantic coast, especially during summer months. These include the following new records of $A$. nodosa: Parada 1 , Punta del Este, (an alive and complete stranded female, F. S. col., January 2000) and Muelle de Mailhos, Punta del Este (two dead females and one "shell" in the beach drift, F. S. col., January 2001). This seasonal and scarce but periodic occurrence is a common pattern observed in the Uruguayan Atlantic coast.

Hochberg et al. (1992) claim that in other coasts, mass stranding of Argonauta comprising "hundreds or even thousands of individuals" occasionally occurs (see also Okutani \& Kawaguchi 1983). Such an event has never been recorded along the Uruguayan coast at least during the last 40 years (Demicheli pers. obs.).

Therefore it was extremely unusual to find more than a hundred egg chambers ("shells") of $A$. nodosa stranded at La Paloma (Rocha) (Fig. 1), between January and April 2004. The state of conservation of 
these "shells", in spite of their fragility and the fact that these do not float by themselves, implies that the individuals died very near the shore. A dozen of "shells" were also recorded at the end of January at La Coronilla (Rocha). At the same time, hundreds complete argonauts were collected at Maldonado (Gorriti Island, Punta del Este, Piriápolis, Playa Hermosa, Playa Verde and Las Flores), most of them still alive. Even at the estuarine coast of Canelones (San Luis and Santa Lucía del Este), inside the Río de la Plata, a few living specimens were collected, being the first record in this estuary. So, the coastal strip covered by this mass stranding implying many hundreds of $A$. nodosa stranded was more than $250 \mathrm{~km}$ long (Fig. 1).

We found that such unusual occurrence was caused by atypical oceanographic and meteorological conditions. It seems that oceanic water masses carrying
A. nodosa were pushed towards the coast and also entered in the Río de la Plata. The Río de la Plata usually flows in NE direction along the Uruguayan coast in fall-winter, reaching Brazilian coast (Piola et al. 1999, 2000, Campos et al. 1999). In spring-summer period the minimum riverine discharge and the prevailing winds produce a constrained influence (Guerrero et al. 1997, Piola 2002). Subtropical Water (STW) (Emilsson 1961, Thomsen 1962) and Tropical Water (TW) (Sverdrup et al. 1942) usually flow southward in the neighborhood of the shelf break, showing greater influence over the Uruguayan shelf during summer-autumn period (Ortega \& Martínez 2006). Negative precipitation anomalies were recorded for the region from January to April 2004 (Fig. 2). This abnormal meteorological condition determined an extremely reduced discharge of the Río de la Plata; this extreme ebb was also predicted for Paraná river,

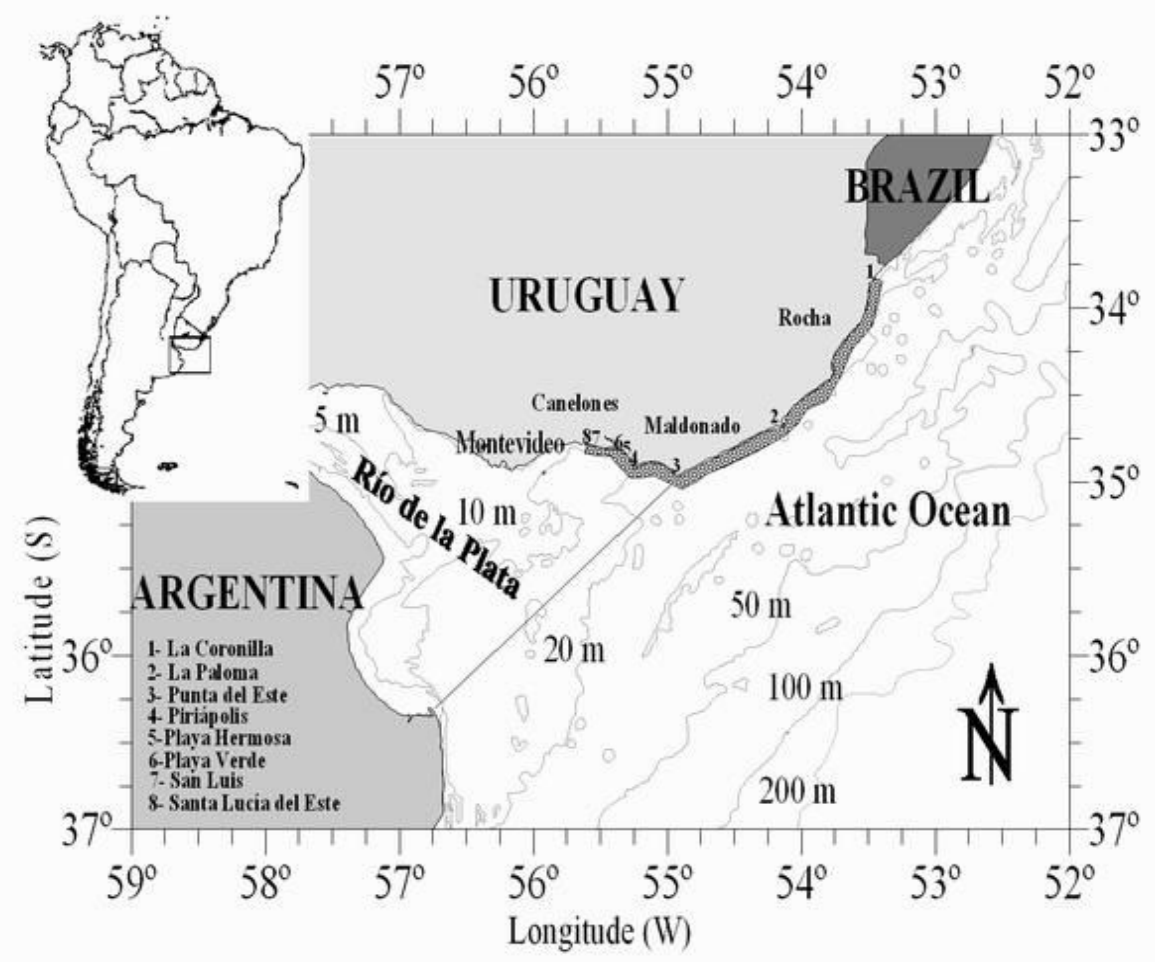

Figure 1

\section{Map of the study area with the main localities (numbered 1 to 8) where specimens of Argonauta nodosa were captured.} Shadow area shows the coastal strip covered by the mass stranding

Mapa del área de estudio con las principales localidades (numeradas 1 a 8) donde se capturaron especímenes de Argonauta nodosa. El área sombreada muestra la extensión de costa cubierta por el varamiento masivo 
the main affluent of the Río the la Plata, by Robertson et al. (2001). As a result of that scarce Río de la Plata discharge, an enhanced coastal flow of oceanic warm waters occurs. This feature is in agreement with a period of higher daily shore water temperatures recorded at La Paloma (Fig. 3) compared with other temporal data (Mazzetta \& Gascue 1995). It is also supported by the sea surface temperature (SST) records from satellite images, resulting in SST positive anomalies for the region along this period ${ }^{1}$. The evolution of SST was recorded from the analysis of monthly level-3 standard mapped satellite images (SST Aqua-MODIS) (Fig. 4). January was characterized by the influence of oceanic warm waters around coastal areas while February and March showed the influence of warmer water at the oceanic region. April showed the retraction of oceanic warm waters and the incipient develop of a core of oceanic cold waters from the south, but the influence of oceanic warm waters was still evident at coastal areas. Moreover, the wind pattern observed during the period from January to March, i. e. sustained SE winds, is unusual for the season (Demicheli pers. obs.) and would favor the advection of oceanic waters to the coast (Odebrecht et al. 1995). These joined features made possible the presence of argonauts on the coast. Maximum number of $A$. nodosa in La Paloma and Maldonado Bay was collected in April, coinciding with the maximal SST anomaly ${ }^{2}$. This oceanographic anomaly is also biologically supported by the unique presence of other warm water organisms in the Río de la Plata estuary such as stranded objects with stalked barnacle Lepas sp. and the Columbus crab Planes sp., as well as the medusa Rhizostoma sp. and the recruitment of the ghost crab Ocypode quadrata (Fabricius, 1787), all in Carrasco Beach, Montevideo (May 14 2004).

During trawling stations onboard the $\mathrm{R} / \mathrm{V}$ Aldebaran, a few specimens of $A$. nodosa were collected on the Uruguayan shelf near the $50 \mathrm{~m}$ isobath

${ }^{1}$ https://www.fnmoc.navy.mil/PUBLIC/OTIS/otis_archive2002.html.

Fleet Numerical Meteorology and Oceanograpy Center. U.S Government Web Site. Fecha de consulta 13/02/2006.

http://www.ncdc.noaa.gov/oa/climate/research/sst/2004weekly-

sst.html. R. Reynolds \& D. Levinson. NOAA/ National Climatic Data

Center. Asheville, North Carolina. Fecha de consulta 13/02/2006.

${ }^{2}$ https://www.fnmoc.navy.mil/PUBLIC/OTIS/otis_archive2002.html.

Fleet Numerical Meteorology and Oceanograpy Center. U.S Government Web Site. Fecha de consulta 13/02/2006.

http://www.ncdc.noaa.gov/oa/climate/research/sst/2004weekly-

sst.html. R. Reynolds \& D. Levinson. NOAA/ National Climatic Data

Center. Asheville, North Carolina. Fecha de consulta 13/02/2006.
(35'30'S-53 $10^{\circ} \mathrm{W}$ ), and hundreds of live specimens were sought around the ship attracted by lights in the same zone, both in autumn 1996 (Martínez \& Ortega pers. obs.). Nevertheless, this zone is part of a yearly monitored area and only in this case argonauts were detected, establishing that the presence of $A$. nodosa is unusual. The period in which this observation was made corresponded to an ENSO cold (La Niña) moderate episode $^{3}$, which is characterized by negative precipitation anomalies for southern South America (Pisciottano et al. 1994, Díaz et al. 1998, Cazes-Boezio et al. 2003). As mentioned above, this meteorological condition determines a lower discharge of the Río de la Plata estuary, enhancing the influence of TW and STW over the Uruguayan shelf. The mixture with Coastal Water (CW) (Guerrero \& Piola 1997) may reach the coast allowing the presence of argonauts. In this case, a mass stranding was not registered maybe due to unfavorable wind conditions or because of the intensity and duration of the event. In fact, the predicted ebb for Paraná river during 2004 was stronger than expected from a moderate La Niña event (Robertson et al. 2001).

In southermost Brazilian waters, $A$. nodosa has been reported during all seasons from stomach contents of yellowfin tuna (Thunnus albacares) and blue shark (Prionace glauca) (Vaske Jr. \& Castello 1998, Vaske Jr. \& Rincón-Filho 1998) caught in open sea pelagic regions. Despite the presence of argonauts larvae in the shelf of this region (Haimovici pers. comm.) it is here hypothized that the normal and whole-year habitat of $A$. nodosa in Uruguayan waters is the open sea subtropical water masses. dos Santos \& Haimovici (2001) already mentioned that pelagic octopuses are more abundant in the outer shelf and oceanic waters; this is in conflict with its findings of $A$. nodosa as relatively frequent in stomach contents of the franciscana (Pontoporia blainvillei), an inner-shelf inhabiting small cetacean. The argonauts were probably ingested during summer or an episode of oceanic influence on coastal waters.

\footnotetext{
${ }^{3}$ http://www.cpc.ncep.noaa.gov/products/analysis_monitoring/ensostuf f/ensoyears.shtml. NOAA/National Weather Service. Climate Prediction Center. Fecha de consulta 13/02/06.
} 


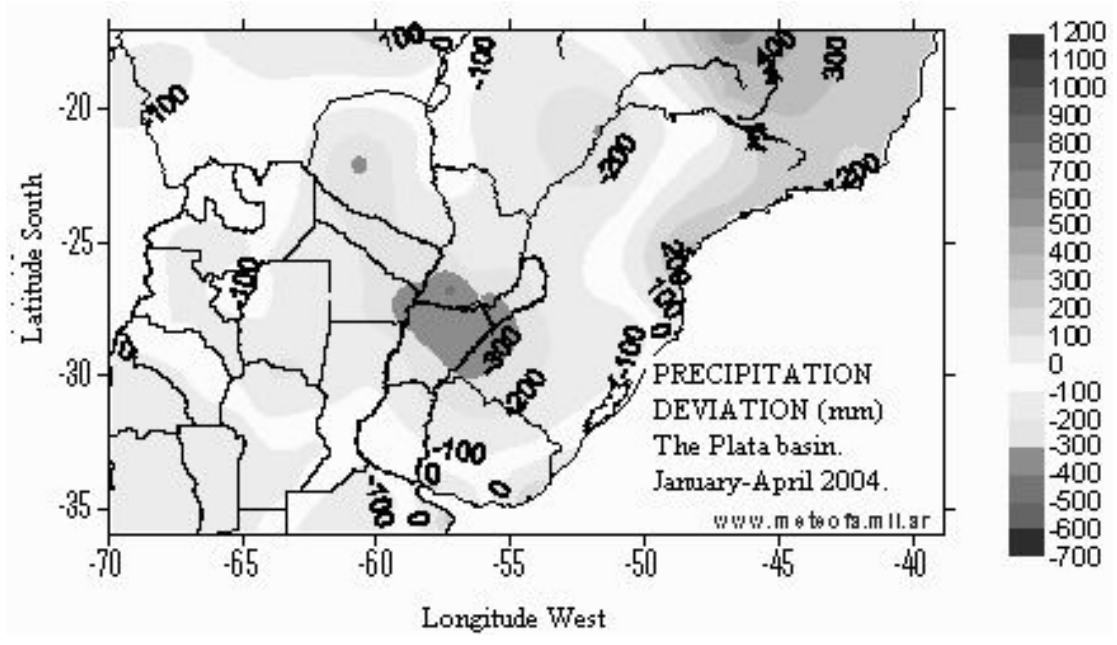

Figure 2

Precipitation deviation in the Plata basin for the period January-April 2004 (from www.meteofa.mil.ar)

Desviación de precipitación para la cuenca del Plata durante el período enero-abril 2004 (fuente www.meteofa.mil.ar)

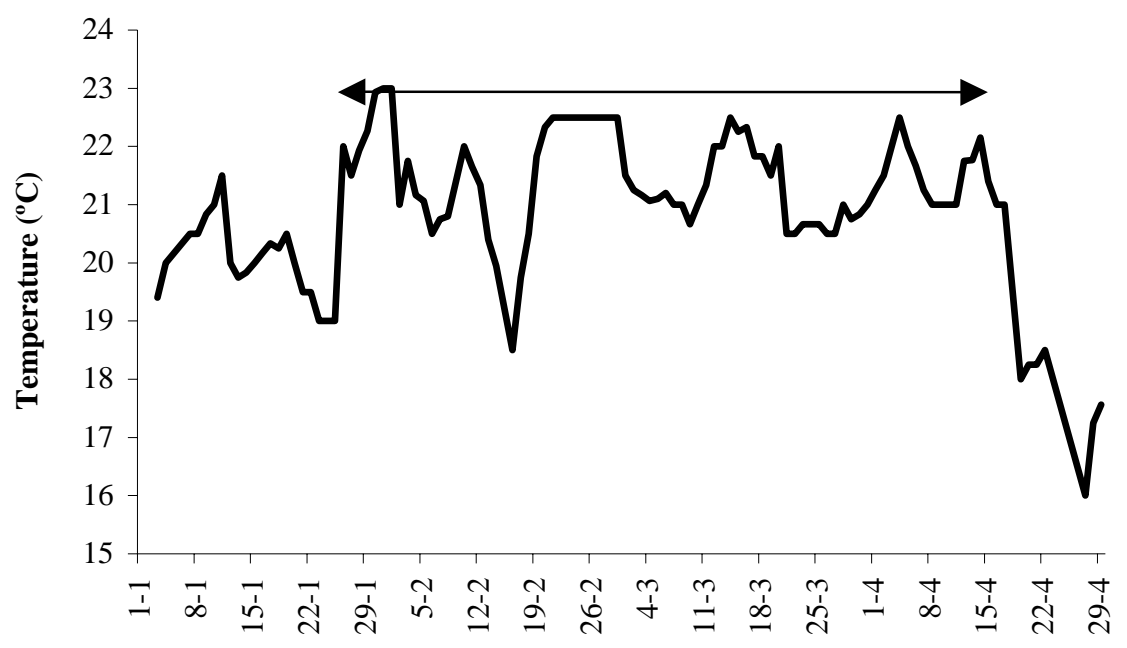

Date

Figure 3

Daily shore water temperature records of La Paloma from January to April 2004.

Arrows show the period of anomalous temperature

Registros diarios de la temperatura del agua costera en La Paloma desde enero hasta abril 2004.

Las flechas indican el período de anomalía 


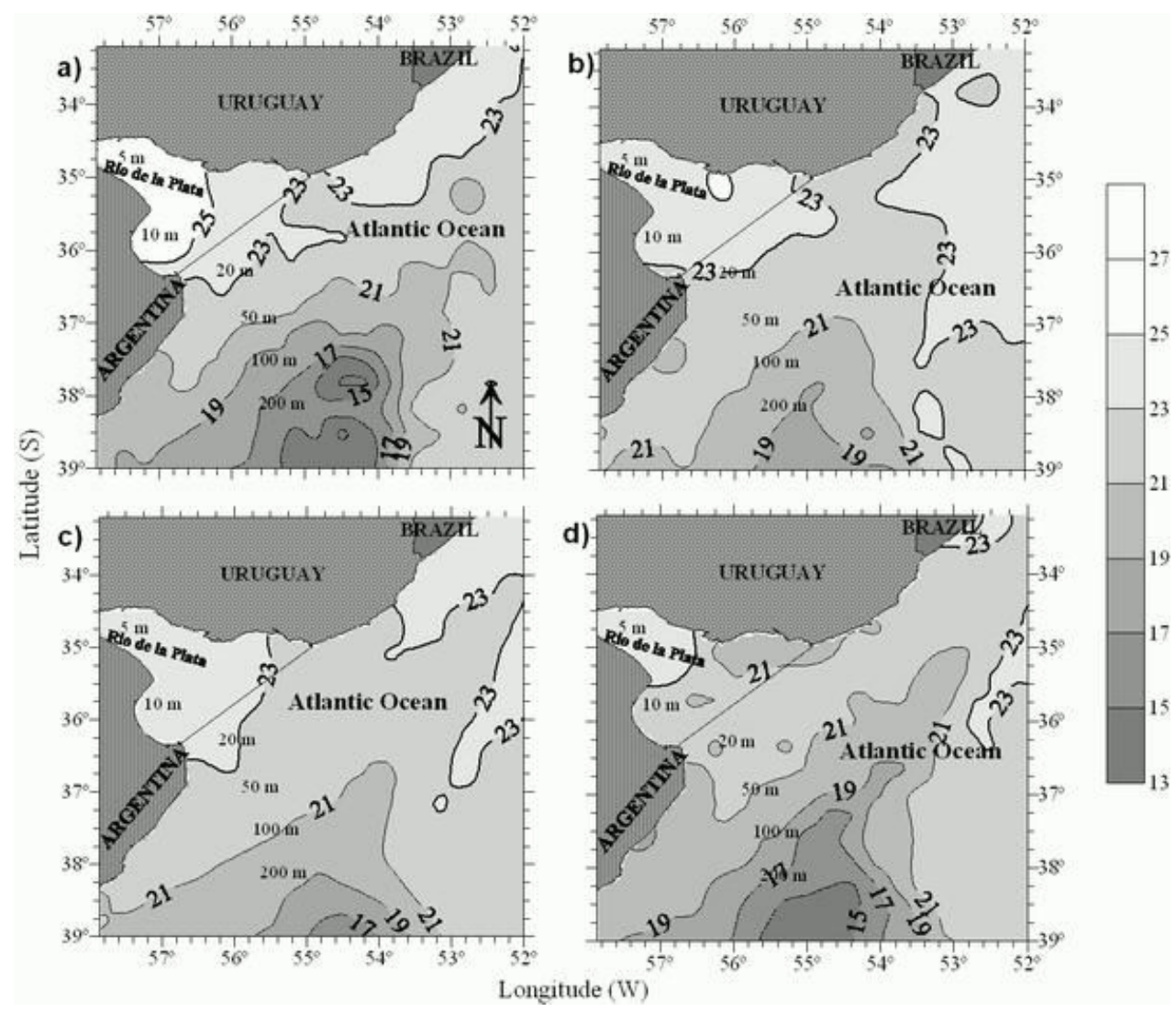

Figure 4

Evolution of Sea Surface Temperature (from SST Aqua-MODIS) during the period of anomalous temperatures. a) January, b) February, c) March, d) April

Evolución de la temperatura superficial del mar (obtenido de STT Aqua-MODIS) durante el período de temperaturas anómalas. a) Enero, b) Febrero, c) Marzo, d) Abril

Pastorino \& Tamini (2002) reported A. nodosa from Argentine waters based on "shells" deposited long ago in the Museum of Buenos Aires (no date recorded) and recently collected material. Although it was not stated in the publication, Pastorino (pers. comm.) informed that this recently collected material was obtained in May 2001. The presence of A. nodosa in Argentinean waters is sporadic, and would also respond to exceptional oceanographic and meteorological conditions.

The outstanding morphological characteristics and the stenotermic condition of the Argonautids point out them as useful indicators of unusual oceanographic conditions, as well as warming trends as was reported by Guerra et al. (2002)
Voucher material for the records here provided is deposited in the Museo Nacional de Historia Natural y Antropología (Montevideo, Uruguay).

\section{Acknowledgments}

We thanks DINARA and Centro Interdisciplinario para el Desarrollo (Montevideo) for the support. We are grateful to ECOPLATA II Project, W. Norbis (DINARA), G. Pastorino (Museo Argentino de Ciencias Naturales "Bernardino Rivadavia”, Buenos Aires), G. Spada (Paris) and F. Mañé-Garzón (Montevideo) for literature. Members of the Sociedad Malacológica del Uruguay, C. Ayçaguer (Instituto de Investigaciones Pesqueras, Facultad de Veterinaria, Montevideo), J. Chocca (DINARA), G. Failla (Sección Zoología Invertebrados, 
Facultad de Ciencias, Montevideo), C. Friss de Kereki (Montevideo) and J. F. Meriana (Punta del Este) provided additional information on the stranding, and DINARA scientific staff at La Paloma supplied temperature data. M. Haimovici (Fundação Universidade Federal do Rio Grande, Brazil) provided comments on an earlier version of this note and literature. V. and D. Cordero (La Paloma) assisted collecting materials. We extend our gratitude to all of them. We finally acknowledge the comments of two anonymous reviewers who read the manuscript.

\section{Literature cited}

Barattini LP \& EH Ureta. 1961 (“1960”). La fauna de las costas del este (invertebrados). Publicaciones de Divulgación Científica, Museo "Dámaso Antonio Larrañaga”, 108 pp. Montevideo.

Campos EJD, CAD Lentini, JL Miller \& AR Piola. 1999. Interannual variability of the sea surface temperature in the south Brazil Bight. Geophysical Research Letters 26(14): 2061-2064

Cazes-Boezio G, AW Robertson \& CR Mechoso. 2003. Seasonal dependence of ENSO teleconnections over South America and relationships with precipitation in Uruguay. Journal of Climate 16: 1159-1176.

Díaz AF, CD Studzinski \& CR Mechoso. 1998. Relationships between precipitation anomalies in Uruguay and southern Brazil and sea surface temperature in the Pacific and Atlantic Oceans. Journal of Climate 11: 251271.

dos Santos RA \& M Haimovici. 2001. Cephalopods in the diet of marine mammals stranded or incindentally caught along southeastern and southern Brazil (21-34 $\left.{ }^{\circ} \mathrm{S}\right)$. Fisheries Research 52: 99-112

Emilsson I. 1961. The shelf and coastal waters off southern Brazil. Boletim do Instituto Oceanográfico da Universidade de São Paulo 11: 101-112.

Figueiras A \& OE Sicardi. 1974. Catálogo de los moluscos marinos del Uruguay. Parte IX. Comunicaciones de la Sociedad Malacológica del Uruguay 3: 323-352.

Guerra A, AF González \& F Rocha. 2002. Appearance of the common paper nautilus Argonatua argo related to the increase of the sea surface temperature in the north-eastern Atlantic. Journal of the Marine Biological Association of the United Kingdom 82: 855-858.

Guerrero RA \& AR Piola. 1997. Masas de agua en la plataforma continental. In: Boschi EE (ed), El mar
Argentino y sus recursos pesqueros 1: 107-118. Instituto Nacional de Investigación y Desarrollo Pesquero, Mar del Plata, Argentina.

Guerrero RA, EM Acha, MB Framiñan \& CA Lasta. 1997. Physical oceanography of the Río de la Plata estuary, Argentina. Continental Shelf Research 17: 727-742.

Haimovici M \& JM Andriguetto. 1986. Composição de espécies e distribuição de cefalópodes costeiros do Rio Grande do Sul. Arquivos de Biologia e Tecnologia do Paraná 29: 373-395.

Hochberg FG, M Nixon \& RB Toll. 1992. Octopoda. In: Sweeney MJ, CFE Roper, KM Mangold, MR Clarke \& SV Boletzky (eds). "Larval" and juvenile cephalopods: a manual for their identification, Smithsonian Contributions to Zoology 513: 213-279.

Juanicó M \& M Rodríguez-Moyano. 1976 ("1975"). Composición faunística de la comunidad de Mytilus edulis platensis d'Orbigny, 1846, ubicada a unas 55 millas al SE de La Paloma. Comunicaciones de la Sociedad Malacológica del Uruguay 4: 113-116.

Leta H R. 1983. Distribución de algunas especies de cefalópodos del frente oceánico uruguayo. Resúmenes y Comunicaciones de las Jornadas de Ciencias Naturales (Montevideo) 3: 68-69.

Mazzetta GV \& FJ Gascue. 1995. Estudio comparativo del comportamiento de la salinidad, la temperatura y el nivel medio del mar en las costas de Montevideo y La Paloma. Atlântica 17: 5-16.

Nión H, C Ríos, JC Elgue, R Varela \& O Pin. 1983. Descripción de un área de cría multiespecífica en el frente oceánico del Uruguay. Resúmenes y Comunicaciones de las Jornadas de Ciencias Naturales (Montevideo) 3: 79-80.

Odebrecht C, AZ Segatto \& CA Freitas. 1995. Surf-zone chlorophyll $a$ variability at Cassino Beach, Southern Brazil. Estuarine, Coastal and Shelf Science 41: 81-90.

Okutani T \& T Kawaguchi. 1983. A mass occurrence of Argonauta argo (Cephalopoda: Octopoda) along the coast of Shimane Prefecture, Western Japan Sea. Venus 41: 281-290.

Ortega L \& A Martínez. 2006. Multiannual and Seasonal Variability of Water Masses and Fronts Over the Uruguayan Shelf. Journal of Coastal Research 23(1) in press.

Pastorino G \& L Tamini. 2002. Argonauta nodosa Solander, 1786 (Cephalopoda: Argonautidae) in Argentine waters. Journal of Conchology 37: 477-482. 
Piola AR. 2002. El impacto del Plata sobre la plataforma continental. In: Schnak EJ (ed), Taller El Niño: sus impactos en el Plata y en la Región Pampeana. La Plata, Argentina: Comisión de Investigación Científica de la provincia de Buenos Aires, Asociación Bonaerense de Científicos, Facultad de Ciencias Naturales y Museo de La Plata, pp. 19-22.

Piola AR, EJD Campos, OO Jr Möller, M Charo \& C Martínez. 1999. Continental shelf water masses off eastern South America $20^{\circ}$ to $40^{\circ}$ S. Proceedings of the $10^{\text {th }}$ Symposium on Global Change Studies. Dallas, Texas, USA. Pp. 446-449.

Piola AR, EJD Campos, OO Jr Möller, M Charo \& C Martínez. 2000. The subtropical shelf front off eastern South America. Journal of Geophysical Research 105(C3): 6565-6578.

Pisciottano G, A Díaz, G Cazes \& C R Mechoso. 1994. El Niño-Southern Oscillation impact on rainfall in Uruguay. Journal of Climate 7: 1286-1304.
Robertson AW, CR Mechoso \& NO Garcia. 2001. Interannual prediction of the Paraná river. Geophysical Research Letters 28: 4235 - 4238.

Scarabino F. 2003. Lista sistemática de los Cephalopoda vivientes de Uruguay. Comunicaciones de la Sociedad Malacológica del Uruguay 8: 197-202.

Sverdrup HU, M Johnson \& R Fleming. 1942. The Oceans. Their physics, chemistry and general biology, 1087 pp. Prentice Hall, New York.

Thomsen H. 1962. Masas de agua características del Océano Atlántico (parte Sudoeste). Buenos Aires: Servicio de Hidrografía Naval, Secretaría Marina, Publ H632: 1-27.

Vaske TJr \& JP Castello. 1998. Conteúdo estomacal da albarco-laje, Thunnus albacares, durante o inverno e a primavera no sul do Brasil. Revista Brasileira de Biología 58 (4): 639-647.

Vaske TJr \& G Rincón-Filho. 1998. Conteúdo estomacal dos tuburaões azul (Prionace glauca) e anequim (Isurus oxyrhinchus) em águas oceânicas no sul do Brasil. Revista Brasileira de Biología 58 (3): 445-452. 